\section{Birlesik Dünya Arastırma New Trends and Issues BD-CENTER Proceedings on Humanities and Innovasyon ve Yayıneılık Merkezi \\ Social Sciences}

Volume 8, Issue 2, (2021) 27-36 www.prosoc.eu

Selected paper of Selected papers of 11th World Conference on Educational Technology Researches (WCETR-2021) 02-03 June 2021

University of Kyrenia, Kyrenia, Cyprus

(ONLINE VIRTUAL CONFERENCE)

\title{
Analysis of the opinions of academists in the field on the applicability of distance education in preschool education
}

Serdal Seven, Prof. Dr. Fatih Sultan Mehmet Foundation University, Istanbul, Turkey

Enes Yurek*, Preschool Teacher, Sahinler Special Education and Rehabilitation Center, Istanbul, Turkey

\section{Suggested Citation:}

Seven, S. \& Yurek, E. (2021). Analysis of the opinions of academists in the field on the applicability of distance education in preschool education. New Trends and Issues Proceedings on Humanities and Social Sciences. 8(2), 27-36. Available from: www.prosoc.eu

Received from June 11, 2021; revised from July 20, 2021; acceptedfrom September 13, 2021.

Selection and peer review under responsibility of Prof. Dr. Huseyin Uzunboylu, Higher Education Planning, Supervision, Accreditation and Coordination Board, Cyprus.

${ }^{\circledR} 2021$ Birlesik Dunya Yenilik Arastirma ve Yayincilik Merkezi. All rights reserved.

\begin{abstract}
The goal of this study is to examine the views of academicians working in the preschool teaching department on the applicability of the distance education model in preschool education. The study was carried out in a 'phenomenological' pattern, which is a qualitative research pattern. The research group comprised eight academicians working in preschool teaching departments of state/foundation universities in Istanbul during the 2020-2021 academic period. The study results indicate that participants expressed more limitations than positive aspects of applying the distance education model in preschool education. It is observed that participants agree that children will face some limitations in socio-emotional development fields, but might be supported in the cognitive development field when the distance education model is applied in preschool education. It is also understood that participants do not have a common view on language development, motor development and self-care skills. Inner-service training for inexperienced teachers on distance education to inform them about distance education practices in preschool education is suggested.
\end{abstract}

Keywords: Preschool education, distance education, academician, child, opinions.

\footnotetext{
* ADDRESS FOR CORRESPONDENCE: Enes Yurek, Preschool Teacher, Sahinler Special Education and Rehabilitation Center, Istanbul, Turkey.

E-mail address: enesyurek22@gmail.com / Tel.: +90-507-0832584

This study is derived from the master thesis of the second author.
} 
Seven, S. \& Yurek, E. (2021). Analysis of the opinions of academists in the field on the applicability of distance education in preschool education. New Trends and Issues Proceedings on Humanities and Social Sciences. 8(3), 027-036. Available from: www.prosoc.eu

\section{Introduction}

The concept of distance education was first mentioned in 1892 in the catalogue of Wisconsin University and then used in 1906 in an article by William Lighty, a director of this university (Verduin \& Clarck, 1994). The first practices of distance education were in the form of correspondence teaching in the early 1700s and then involved technology by using audio and visual tools at schools in the first half of the 1900s (Jeffries, 2008).

Distance education has been applied by means of a wide range of tools since the first day examples of distance education were seen in the world. Moore and Kearsley (2011) put these tools in the following chronological order: correspondence/letter, radio and television broadcasting, teleconference/videoconference and computer/Internet/web tools.

Distance learning practices, once a dream for the past civilisations, have currently become quite easy to realise with the advent of technological developments (Isman, 2011). Examples of distance education practices have been seen in various levels of education for years in our country. The first Open Education Faculty in Higher Education level was opened within Eskisehir Anatolian University in 1982, followed by Open Education High School in 1992 and Open Education Primary School in 1997 with the permission of the Ministry of National Education (Usun, 2006). Today, these institutions keep working actively in addition to open and distance education/training practices in many other universities in higher education level.

The occurrence of the COVID-19 epidemic, which has influenced the whole world and had deep impacts on our lives for one and a half year, has also influenced the field of education, leading to the suspension of face-to-face education in many countries. As in other cases of epidemics in history, various options have been evaluated in order to continue education during the COVID-19 epidemic (Yildirim, 2021). Facilities provided by the century we are in have turned digital learning into a lifesaver during this epidemic process (Karp \& McGowan, 2020; cited by Yildirim, 2021).

Distance education, which is effectively applied with students of higher levels of education, has various limitations for younger preschool students whose attention span is shorter (McNeill, 2020). As preschool children learn best through peer interaction, tangible experiences and by doing, living, using their senses, playing and moving, they are considered to be the group which is exposed to most limitations in distance education (Hao, 2020).

As mentioned above, some questions arise in the context of applicability of distance education in preschool education, which puts an emphasis on tangible materials, sensory learning and socialisation. Examples of distance education practices are not very often seen in preschool education, although the first examples of distance education were introduced centuries ago and used in all levels of education for years. Therefore, the number of studies on this subject is very limited in literature.

Taking the literature limitation into account, the goal of this study is to examine the views of academicians in the preschool teaching department on applicability of the distance education model in preschool education and seek for answers to the following questions:

1. Which aspects of the distance education model in preschool education do academicians working in the preschool teaching department find positive?

2. Which aspects of the distance education model in preschool education do academicians working in the preschool teaching department find limited?

3. Which development fields of children do academicians working in the preschool teaching department think can be improved with the distance education model in preschool education?

4. Improvement of which development fields of children do academicians working in the preschool teaching department think might face limitations with the distance education model in preschool education? 
5. How do academicians working in the preschool teaching department think education might be evaluated when the distance education model is applied in preschool education?

\section{Method}

\subsection{Research model}

Qualitative research is defined as 'a study that follows a qualitative process where qualitative data collection tools such as observation, interview and document analysis are used and perceptions and phenomena are revealed in a natural setting with a realistic and holistic approach' (Yildirim \& Simsek, 2011, p. 39). Phenomenology, one of the qualitative research patterns, was used in this study to reveal the views of academicians in preschool teaching departments on the applicability of the distance education model in preschool education. Phenomenology focuses on phenomena that 'we are aware of but do not have a deep and detailed understanding. Phenomena occur in our world as 'events, experiences, perceptions, concepts and cases' (Yildirim \& Simsek, 2011, p. 72).

\subsection{Research group}

The research group of this study was identified with criterion sampling, which is one of the purposeful sampling methods. The research group of a study might consist of people, cases, situations or objects that meet certain criteria (Seven \& Seven, 2020). The research group of this study consist of individuals who met predetermined criteria, consisting of eight academicians who worked in the 'preschool teaching departments' of state/foundation universities in Istanbul during the 2020-2021 academic period (four academicians from state universities and four academicians from foundation universities). They were selected according to the following predetermined criteria: achieving minimum a doctorate degree, having minimum 3 years active working experience in the 'preschool teaching' department, following and adapting to actual and technological developments.

\subsection{Data collection tools}

The data collection tools used in this study are 'demographic form' and 'semi-structured interview form' developed by the authors. The demographic form involves demographic features of the participant academicians and proves that they met the study inclusion criteria. The semi-structured interview form is a form developed according to the goals and sub-goals of the study and the ultimate form with the views of five field experts was used.

\subsection{Data collection and analysis}

Data of this study were collected through interviews between the authors and participants. The interviews were conducted between November 2020 and January 2021. All interviews were conducted online due to the COVID-19 epidemic. Interviews were recorded and then transcribed for analysis. (Academicians participated in the study voluntarily and consented to interview recording.) Names of participants were not used and each participant was given a code number while dealing with the data.

Study data were analysed with a combination of both content analysis and descriptive analysis, which are qualitative analysis methods. Data obtained with descriptive analysis are summarised and interpreted by means of predetermined themes; they might also be ordered according to the themes derived from research questions and presented in the context of questions and various aspects used during interview-observation stages (Yildirim \& Simsek, 2011). On the other hand, the basic job in content analysis is to bring associated data together under certain concepts and themes, order and interpret them in a way that readers could understand (Yildirim \& Simsek, 2011). 
In this study, each interview question was separately presented during data analysis (only the third and fourth questions were dealt with together). From this point of view, a frame was structured as the first step of descriptive analysis and each interview question was analysed by following the steps defined by Yildirim and Simsek (2011, p. 228) as 'the first stages of content analysis: coding the data, determining the themes, ordering the codes and themes and defining the findings'.

\section{Findings and interpretation}

\subsection{Positive aspects of distance education in preschool education}

Table 1 displays the findings derived from the responses of academicians working in the preschool teaching department to the questions posed in order to reveal their views on what might be the positive aspects of the distance education model in preschool education.

Table 1. Themes, codes, participants and frequencies in the main theme of positive aspects of distance education in preschool education

\begin{tabular}{llll}
\hline \multicolumn{1}{c}{ Themes } & \multicolumn{1}{c}{ Codes } & Participants & $f$ \\
\hline & $\begin{array}{l}\text { Keeping it touch with } \\
\text { friends/teachers }\end{array}$ & P3, P4, P8 & 3 \\
& $\begin{array}{l}\text { Providing stimulants } \\
\text { Supporting effective }\end{array}$ & P1, P2, P5 & 3 \\
teaching & Inclusion of the family in education & P2, P8 & 2 \\
& Access to all children & P5 & 1 \\
Supporting the & Entertaining education & P5 & 1 \\
teacher & Compensating the teacher's & P5 & 1 \\
& shortcomings & & \\
& None at all & P6, P7 & 2 \\
\hline
\end{tabular}

According to Table 1, academicians think that applying the distance education model in preschool education might have positive aspects, although few academicians suggest that applying distance education in preschool education might create a positive situation by 'supporting effective teaching' and 'supporting the teacher'. Academicians point out several benefits of applying distance education in preschool education in the context of supporting effective teaching such as maintaining the interaction of children with their friends and teachers by means of distance education tools, providing plenty of audio and visual stimulants to children with the help of distance education tools, involving families more actively in education process, having access to all children including those who do not come to school under usual circumstances and having fun while learning. It is also considered that the distance education model might support teachers by helping them compensate their shortcomings. On the other hand, two of the eight participant academicians think that applying the distance education model will have no positive aspect at all. Below are some quotations to form a basis for these views.

Keeping in touch with teachers/friends: 'Children, who have to stay at home and lose social activity for a long time, might interact with their friends and teachers on-line for 15 minutes or two separate 15 minutes a day' (PA3).

Providing stimulants: 'Distance education might have supported education by providing more visual support. This is the positive aspect' (PA2).

Compensating teacher's shortcomings: 'Teachers who have very good knowledge of technology can visualise what they dream on the screen. They might not be good at singing, making children play, reading stories. They can absolutely use technology to apply techniques that they have to do themselves' (PA5). 
None at all: 'Considering their developmental features, I think that this distance education model will not be appropriate in preschool education' (PA6).

\subsection{Limited aspects of the distance education model in preschool education}

Table 2 displays the findings derived from the responses of academicians working in the preschool teaching department to the interview questions posed in order to reveal their views on what might be the limitations of the distance education model in preschool education.

Table 2. Themes, codes, participants and frequencies in the main theme of limitations of distance education in preschool education

\begin{tabular}{|c|c|c|c|}
\hline Themes & Codes & Participants & $f$ \\
\hline \multirow{13}{*}{ Children's limitations } & Limited interaction & P3, P4, P5, P6 & 4 \\
\hline & $\begin{array}{l}\text { Inappropriate for } \\
\text { developmental features of } \\
\text { children }\end{array}$ & P1, P4, P7, P8 & 4 \\
\hline & Lack of socialisation & P2, P3, P5 & 3 \\
\hline & Technological addiction & P3, P4, P5 & 3 \\
\hline & $\begin{array}{l}\text { Limited technological } \\
\text { knowledge of children }\end{array}$ & P2, P4, P5 & 3 \\
\hline & Screen time limitation & P5, P7 & 2 \\
\hline & Inappropriate for the age & P1, P3 & 2 \\
\hline & Easily bored children & P1, P6 & 2 \\
\hline & Limited attention span & P6, P8 & 2 \\
\hline & $\begin{array}{l}\text { Inability to keep the child on } \\
\text { screen }\end{array}$ & P6, P7 & 2 \\
\hline & Causing health problems & P3, P5 & 2 \\
\hline & Limited peer interaction & $\mathrm{P} 2$ & 1 \\
\hline & Deprivation of school facilities & P4 & 1 \\
\hline \multirow[t]{3}{*}{ Family limitations } & $\begin{array}{l}\text { Too much intervention of the } \\
\text { family }\end{array}$ & $\mathrm{P} 2$ & 1 \\
\hline & Families feeling pressure & P8 & 1 \\
\hline & $\begin{array}{l}\text { Socio-economic privileges of the } \\
\text { family }\end{array}$ & P8 & 1 \\
\hline Teacher limitations & $\begin{array}{l}\text { Limitations in completing } \\
\text { activities }\end{array}$ & $\mathrm{P} 2$ & 1 \\
\hline
\end{tabular}

According Table 2, academicians think that applying the distance education model in preschool education involves limitations in many aspects. It is inferred from the views of academicians that applying distance education in preschool education has many limitations under child, family and teacher themes. It is suggested that applying the distance education model in preschool education poses many limitations in the context of the 'child' as it limits their interaction with friends/teachers; is not appropriate for their age and developmental features; limits socialisation, which is a significant function of school; causes technological addiction among children; causes health problems due to inactivity; and children are quickly bored and leave the screen as their attention span is limited and they are deprived of school facilities. Children receive education at home in the distance education model, resulting in limitations in the context of the 'family' as families are involved in educational process more than necessary, feel pressure as they assume teacher's responsibility and have their 
own socio-economic privileges. It is also considered that applying the distance education model in preschool education has a limitation in the context of the 'teacher' as they are not able to do every activity they wish to do. Below are some quotations to form a basis for these views.

Limited interaction: 'Children interact with their friends, teachers, materials, education programmes, activities and everything else in a classroom setting. Therefore, they are deprived of all these in distance education process' (PA4).

Limited technological knowledge of children: 'Technological skills of children at that age is limited' (PA5).

Screen time limitation: 'As announced by American Paediatric Academy, maximum screen time for children between the ages of 2 and 5 is 1 hour. To begin with, we must not exceed 1 hour' (PA7).

Easily bored children: 'As children do not know how to read and write, the written world becomes too abstract for them and they get bored after a while' (KA1).

Too much intervention by the family: 'It is a fact that parents get involved in the process too much, which might mean directing the child. It might cause some unfavourable conditions for children' (PA2).

Families feeling pressure: 'Here, families might be feeling psychological pressure. It is as if families are expected to assume teacher's role and do all the activities that teachers would do' (PA8).

\subsection{Development of the child with the distance education model in preschool education}

Table 3 displays the findings derived from the responses of academicians working in the preschool teaching department to the interview questions posed in order to reveal their views on which developmental aspects of children might be developed and which aspects might be limited when the distance education model is applied in preschool education.

Table 3. Themes, codes, participants and frequencies in the main theme of effects of distance education in preschool education on children's development

\begin{tabular}{llll}
\hline \multicolumn{1}{c}{ Themes } & \multicolumn{1}{c}{ Codes } & \multicolumn{1}{c}{ Participants } & $\boldsymbol{f}$ \\
\hline & Cognitive development & P1, P2, P3, P4, P5, P6, P7, 8 & 8 \\
& Language development & P1, P3, P4, P6, P7 & 5 \\
& Motor development & P1, P2 & 2 \\
Fields possible to & Self-care skills & P1 & 1 \\
develop & Socio-emotional development & P8 & 1 \\
& Socio-emotional development & P1, P2, P3, P4, P5, P6, P7, P8 & 8 \\
Fields of limited & Motor development & P2, P3, P4, P7 & 4 \\
development & Self-care skills & P2, P7 & 2 \\
\hline
\end{tabular}

According to Table 3, academicians think that some developmental fields of children might be developed and some developmental fields might face limitations when the distance education model is applied in preschool education. All the academicians think that children's cognitive development could be developed, but there could be limitations in socio-emotional development field. According to the findings, academicians think that children's language development is the field that might be developed mostly after cognitive development. They also think that children might be exposed to limitations mostly in the field of motor development after socio-emotional development. It is understood from the table that academicians did not express their views sufficiently on development of self-care skills and a definite statement could not be put forward on this field. Below are some quotations to form a basis for these views. 
Cognitive development: 'Distance education is rather preferred in cognitive development field' (PA3).

Language development: 'For example, children might be involved in conversations for language development. Distance education might be used to help children express themselves. For example, imagine that we use a doll to tell a story to the child. Then, we might chat with the child about the story to investigate his/her opinions and views. We might ask open-ended questions. This is possible. These activities might be done for language development' (PA6).

Socio-emotional development: 'I believe that there might be trouble in the field of socio-emotional development. I don't think a distant social interaction could be as appropriate as face-to-face education' (PA2).

Motor development: 'It is a bit more difficult to use it in the field of psycho-motor skills. For example; speed-flexibility, coordination-manipulative skills, body awareness, they are all hard to deal with' (PA3).

\subsection{Evaluation of the distance education model in preschool education}

Table 4 displays the findings derived from the responses of academicians working in the preschool teaching department to the interview questions posed in order to reveal their views on how to carry out evaluations when the distance education model is adopted in preschool education.

Table 4. Codes, participants and frequencies in the main theme of evaluation methods in the distance education model in preschool education

\begin{tabular}{lll}
\hline \multicolumn{1}{c}{ Codes } & \multicolumn{1}{c}{ Participants } & $\boldsymbol{f}$ \\
\hline Observation with synchronised activities & $\mathrm{P} 1, \mathrm{P} 3, \mathrm{P} 5, \mathrm{P} 6, \mathrm{P} 7, \mathrm{P} 8$ & 6 \\
Family-supported evaluations & $\mathrm{P} 3, \mathrm{P} 4, \mathrm{P} 8$ & 3 \\
Checklists & $\mathrm{P} 2, \mathrm{P} 3, \mathrm{P} 5$ & 3 \\
Digital portfolio & $\mathrm{P} 2, \mathrm{P} 3$ & 2 \\
Gamified cognitive tests & $\mathrm{P} 5, \mathrm{P} 7$ & 2 \\
Anecdotal records & $\mathrm{P} 3, \mathrm{P} 4$ & 2 \\
Paper work & $\mathrm{P} 1, \mathrm{P} 6$ & 2 \\
Video analysis & $\mathrm{P} 2$ & 1 \\
Rubrics & $\mathrm{P} 2$ & 1 \\
Rating scales & $\mathrm{P} 2$ & 1 \\
Development reports & $\mathrm{P} 3$ & 1 \\
Observation forms & $\mathrm{P} 3$ & 1 \\
Job-time charts & $\mathrm{P} 3$ & 1 \\
\hline
\end{tabular}

According to the data displayed in Table 4, academicians think that there are several ways of evaluating the education when distance education model is applied in preschool education. When preschool education is carried out with distance education model, academicians think that education might be evaluated by means of observation during simultaneous activities of teachers and students, feedback from families who are beside their children any time, e-portfolios that we will often hear in education issues from now on, gamified cognitive tests supported by technology, 2-D works on paper, video analysis and forms such as check lists, anecdote records, rubrics, development forms which are also used very often in face-to-face education. Below are some quotations to form a basis for these views:

Observation in synchronised activities: 'If the child and teacher go on-line simultaneously, questions, responses and opinions of the child might be evaluated by the teacher' (PA8).

Digital portfolio: 'Evaluation tools such as portfolio might be used. Now, a portfolio may be prepared by a student taking photos of home activities and products and sending them to the teacher. 
Seven, S. \& Yurek, E. (2021). Analysis of the opinions of academists in the field on the applicability of distance education in preschool education. New Trends and Issues Proceedings on Humanities and Social Sciences. 8(3), 027-036. Available from: www.prosoc.eu

Thus, the teacher might evaluate these products and come to a conclusion on the child's development; for example, observe that the child who could previously count to 5 is now able to count to $10^{\prime}$ (PA2).

Gamified cognitive tests: 'Gamified cognitive test at the end of education is the only indicator of the child's acquisition of the concepts and achievements' (PA7).

Development reports, anecdote records, observation forms, job-time charts and check lists: 'There is evaluation in daily course of education, monthly plan and activity plan. We support these evaluation components with development reports that we issue twice a year. We can also do it with observation forms, anecdote records, job-time charts, check lists and transfer all these data to the digital platform' (PA3).

\section{Discussion and recommendations}

It is understood from the results of this study that academicians working in the preschool teaching department have a cautious view of distant education model practices in preschool education, but think that they might be used in cases where circumstances do not allow face-to-face education or in order to support face-to-face education. The positive aspect of distant education model in preschool education mentioned most by the participants is that it allows children to keep in touch with their teachers and friends and maintain their ties with the school, a view which is supported by another study in the literature (Kuset, Ozgem, Sasmacioglu \& Guldal Kan, 2021). It is also understood that limitations caused by distant education model in preschool education will influence children the most and particularly have an impact on the 'socialisation' aspect. The effect of socialisation and socioemotional development, a significant function of school, on social skills of children in kindergarten and primary school period is supported by studies in the literature (Celik, 2019; Erbay, 2008; Pekdogan, 2011).

Academicians who participated in the study believe that a child's development might be exposed to several limitations due to the distance education model in preschool education. Academicians agree that social-emotional development fields of children will be exposed to significant limitations, but their cognitive development might be supported with distant education. On the other hand, it is understood that academicians do not have a common view of language development, motor development and self-care skills, which are the basic developmental fields of children in preschool education. Despite the lack of a common view, academicians believe that language development of children might be partially supported but there will be significant limitations in motor development. Academicians did not express as sufficient view of self-care skills as to allow us to make a proper interpretation. It is a fact recognised by the whole world that preschool education has a significance that affects the whole lives of children (Sapsaglam, 2018). Studies often reveal findings that support the view that preschool education is a significant factor for a child's academic success in primary school (Johnson, 1996; Shala, 2013; Taiwo \& Tyolo, 2002). Some questions arise about applying the distance education model in preschool education as it is considered that children's cognitive development will be supported to a great extent and language development only in some cases, but there will significant limitations in socio-emotional development and motor development. Considering child development as a whole, it is considered that development of some fields and limitations in other fields of child development with distance education model in preschool education will weaken the contribution of face-to-face education in the following years.

There are also a wide range of views on how the 'evaluation' aspect of preschool education, another conclusion of the study, will be carried out. Even if limited to some methods, participants believe that an evaluation is possible in the distance education model in preschool education. It is considered that observation during synchronised activities that enable simultaneous interaction will give teachers an opportunity for evaluation. Thanks to technological facilities, teachers record synchronised activities, which help them to get rid of the difficulty of observing all the children at one 
time. Teachers might also cooperate with families and do evaluations according to their feedback. Rutland and Hall (2013) emphasise that active role of families in evaluation process is quite important. It is considered that a strong school-family cooperation and inclusion of families in evaluation enables a more effective evaluation process (Ozturk, 2013). Inclusion of families in evaluation process not only provides more data and information to the teacher, but also helps families to explore what they could do for their children's education (Birbili \& Tzioga, 2014). Technological advancements provide other opportunities for evaluation as well. One of them is the digital portfolio. Studies on using e-portfolios in education indicate that teachers have positive opinions (Gok, Bas \& Ayaz, 2020). Additionally, it is considered that checklists, anecdote records and similar forms might be used for evaluation in distance education.

To conclude, inner-service training for inexperienced teachers on distance education to inform them about distance education practices in preschool education is suggested. We might also suggest adding a course in the preschool teaching curriculum of universities on how distance education might be applied in preschool education, supported with practical examples. The role of family is more important in distance education as teachers and children are in separate places. Therefore, families must be informed by authorities on what kind of a role they must assume in distance education, which will allow families to help children and teachers in both practice and evaluation stages of education.

\section{References}

Birbili, M. \& Tzioga, K. (2014). Involving parents in children's assessment: lessons from the Greek context. Early Years: An International Research Journal, 34(2), 161-174. doi:10.1080/09575146.2014.894498

Celik, S. B. (2019, April 18-20). Ilkogretim birinci sinif ogretmenlerinin goruslerine gore okul oncesi egitim almayan ogrencilerin sosyal-duygusal gelisimine etkisi. In H. Karatay (Ed.), VI. Uluslararasi Egitim Bilimleri Sempozyumu, Tam Metin Kitabi (pp. 126-131). Alanya, Turkey: Alaaddin Keykubat Universitesi.

Erbay, E. (2008). Okul oncesi egitim alan ve almayan ilkogretim birinci sinif ogrencilerinin sosyal becerilere sahip olma duzeyleri (Master's thesis). Pamukkale Universitesi/Sosyal Bilimler Enstitusu, Denizli, Turkey.

Gok, B., Bas, O. \& Ayaz, M. (2020). Sinif ogretmenlerinin e-portfolyo hakkindaki gorusleri. Inonu Universitesi Egitim Fakultesi Dergisi, 21(2), 1085-1104. doi:10.17679/inuefd.742503

Hao, W. (2020). Policy update: remote learning in early childhood. National Association of State Boards of Education, 27(6). Retrieved March 26, 2021, from https://nasbe.nyc3.digitaloceanspaces.com/2020/06/Hao_ECE-Remote-Learning-Final.pdf

Isman, A. (2011). Uzaktan Egitim (4th ed.). Ankara, Turkey: Pegem Akademi Yayincilik.

Jeffries, M. (2008). Research in distance education. IHETS. Retrieved May 3, 2021, from http://www.digitalschool.net/edu/DL_history_mJeffries.html

Johnson, R. B. (1996). The effectiveness of preschool education on academic achievement. Retrieved March 23, 2021, from https://files.eric.ed.gov/fulltext/ED400069

Kuset, S., Ozgem, K., Sasmacioglu, E. \& Guldal Kan, S. (2021). Evaluation of the impact of distance education on children in preschool period: teachers' opinions. Near East University Journal of Education Faculty (NEUJE), 4(1), 78-87. doi:10.32955/neuje.v4i1.287

McNeill, J. (2020, April 23). 4 tips for delivering distance learning to Pre-K students. Retrieved March 18, 2021, from https://eab.com/insights/expert-insight/independent-school/tips-for-delivering-distance-learningto-pre-k-students/

Moore, M. \& Kearsley, G. (2011). Distance education: a systems view of online learning (3rd ed.). Belmont, CA: Wadsworth, Cengage Learning.

Ozturk, M. (2013). Family partnership in early childhood assessment. Mediterranean Journal of Social Sciences, 4(3), 679-686. doi:10.5901/mjss.2013.v4n3p679

Pekdogan, S. (2011). Okul oncesi egitim kurumuna devam eden bes alti yas cocuklardaki sosyal becerilerin bazi ozellikler acisindan incelenmesi (Elazig ili ornegi) (Master's thesis). Inonu Universitesi/Egitim Bilimleri Enstitusu, Malatya, Turkey. 
Rutland, J. \& Hall, A. H. (2013). Involving families in the assessment process. Retrieved March 21, 2021, from https://tigerprints.clemson.edu/cgi/viewcontent.cgi?article=1024\&context=eugene_pubs

Sapsaglam, O. (2018). Social media awareness and usage in preschool children. International Journal of Eurasia Social Sciences, 9(31), 728-746.

Seven, Z. D. \& Seven, S. (2020). The investigation of interactional synchrony between 3-year-old children and their mothers according to family types. New Trends and Issues Proceedings on Humanities and Social Sciences, 7(1), 142-148. doi:10.18844/prosoc.v\%vi\%i.4878

Shala, M. (2013). The impact of preschool social-emotional development on academic success of elementary school students. Psychology, 4(11), 787-791. doi:10.4236/psych.2013.411112

Taiwo, A. A. \& Tyolo, J. B. (2002). The effect of pre-school education on academic performance in primary school: a case study of grade one pupils in Botswana. International Journal of Educational Development, 22, 169-180. doi:10.1016/S0738-0593 (01) 00020-7

Usun, S. (2006). Uzaktan Egitim. Ankara, Turkey: Nobel Yayin Dagitim.

Verduin, J. R. \& Clark, T. A. (1994). Uzaktan Egitim: Etkin Uygulama Esaslari (I. Mavis, Trans.). Eskisehir, Turkey: Anadolu Universitesi Basimevi.

Yildirim, B. (2021). Preschool education in Turkey during the COVID-19 pandemic: a phenomenological study. Early Childhood Education Journal. doi:10.1007/s10643-021-01153-w

Yildirim, A. \& Simsek, H. (2011). Sosyal Bilimlerde Nitel Arastirma Yontemleri. (8th ed.). Ankara, Turkey: Seckin Yayincilik. 